Substance Abuse and Mental Health Services Administration Office of Applied Studies

\title{
NATIONAL HOUSEHOLD SURVEY ON DRUG ABUSE: RURAL POPULATION ESTIMATES 1994
}

U.S. DEPARTMENT OF HEALTH AND HUMAN SERVICES

Public Health Service 